\title{
Ultrastructure of Haller's Organ in the Tick Amblyomma americanum (L.)*
}

\author{
R. F. Foelix and R. C. Axtell \\ Department of Entomology North Carolina State University, Raleigh, N. C. 27607
}

Received July 12, 1971

\begin{abstract}
Summary. Haller's organ on the tarsus of the tick Amblyomma americanum (L.) (Acarina: Ixodidae; nymphal stage) was studied by scanning and transmission electron microscopy. It consists of a distal bristle group, (the "anterior pit"), and a proximal "capsule" which encloses several sensilla. The seven sensilla of the anterior pit (A1-A 7) are all thick-walled and multiinnervated (2-9 neurons), but at least three different types can be differentiated. Sensilla A1 and A2 possess large, plugged pores $(>1000 \AA)$ and are the only sensilla with branching dendrites. A3 and A5 are characterized by a spoke-wheel arrangement of the cuticle wall and very fine pores (100-200 $\AA$ ) penetrating the "spokes" centrally; A4, A6, and A 7 do not exhibit any pore system but a single opening at the bristle tip is assumed.

The capsule contains seven thin-walled, blunt-tipped sensilla, and several non-sensory cuticular projections (pleomorphs). All of these sensilla possess large "plugged" pores in the cuticle wall and numerous dendritic branches of several neurons (3-5) in the lumen. Glandular openings were found inside the capsule; their significance is discussed.

The fine structure of Haller's organ supports the functions postulated by Lees (1948), namely olfaction for the capsule and humidity reception (among others) for the anterior pit.

Key words: Sensory receptors-Acarina — Amblyomma americanum — Haller's organ Ultrastructure.

Zusammenfassung. Das Hallersche Organ auf dem Tarsus der Zecke Amblyomma americanum (L.) (Acarina: Ixodidae; Nymphenstadium) wurde mit dem Durchstrahlungs- und Rasterelektronenmikroskop untersucht. Es besteht aus einer distalen Sensillengruppe, die in einer flachen „Wanne" gelegen ist, und einer proximalen „Kapsel“, welche mehrere Sensillen einschließt. Alle sieben Sensillen der „Wanne“ (A 1-A 7) sind dickwandig und mehrfach innerviert (2-9 Neurone), jedoch können mindestens 3 verschiedene Typen unterschieden werden: A 1 und A2 besitzen große Poren $(>1000 \AA)$, die mit Pfropfen versehen sind, und sie sind zudem die einzigen Sensillen mit sich verzweigenden Dendriten; A3 und A5 sind durch eine radspeichenartige Anordnung der Cuticulawandung charakterisiert, ferner durch feine Poren (100-200 §), welche die Speichen zentral durchziehen; A4, A 6, und A 7 zeigen kein Porensystem, doch wird eine einzelne Öffnung an der Spitze vermutet.

Die ,Kapsel" enthält 7 dünnwandige, stumpf endigende Sensillen und mehrere nichtsensorische Cuticulavorsprünge. Alle Sensillen besitzen große „Pfropfporen“ in der Cuticulawandung und zahlreiche dendritische Verzweigungen mehrerer Neuronen (3-5) im Lumen. Drüsenmündungen wurden in der ,Kapsel" festgestellt, ihre Bedeutung wird diskutiert.

Die Feinstruktur des Hallerschen Organs entspricht dem Postulat von Lees (1948), wonach die „Kapsel“ der Geruchsrezeption, die „Wanne" der Feuchtigkeitsrezeption dienen soll.
\end{abstract}

\section{Introduction}

At the close of the last century Haller (1881) described an organ on the tarsus of an ixodid tick, which he believed to function as an auditory organ. Further

* This research was supported in part by the Office of Naval Research, and by NIH Training grant ES 00069. Paper no. 3459 of the Journal Series of the North Carolina State University Agricultural Experiment Station, Raleigh.

19 Z. Zellforsch., Bd. 124 

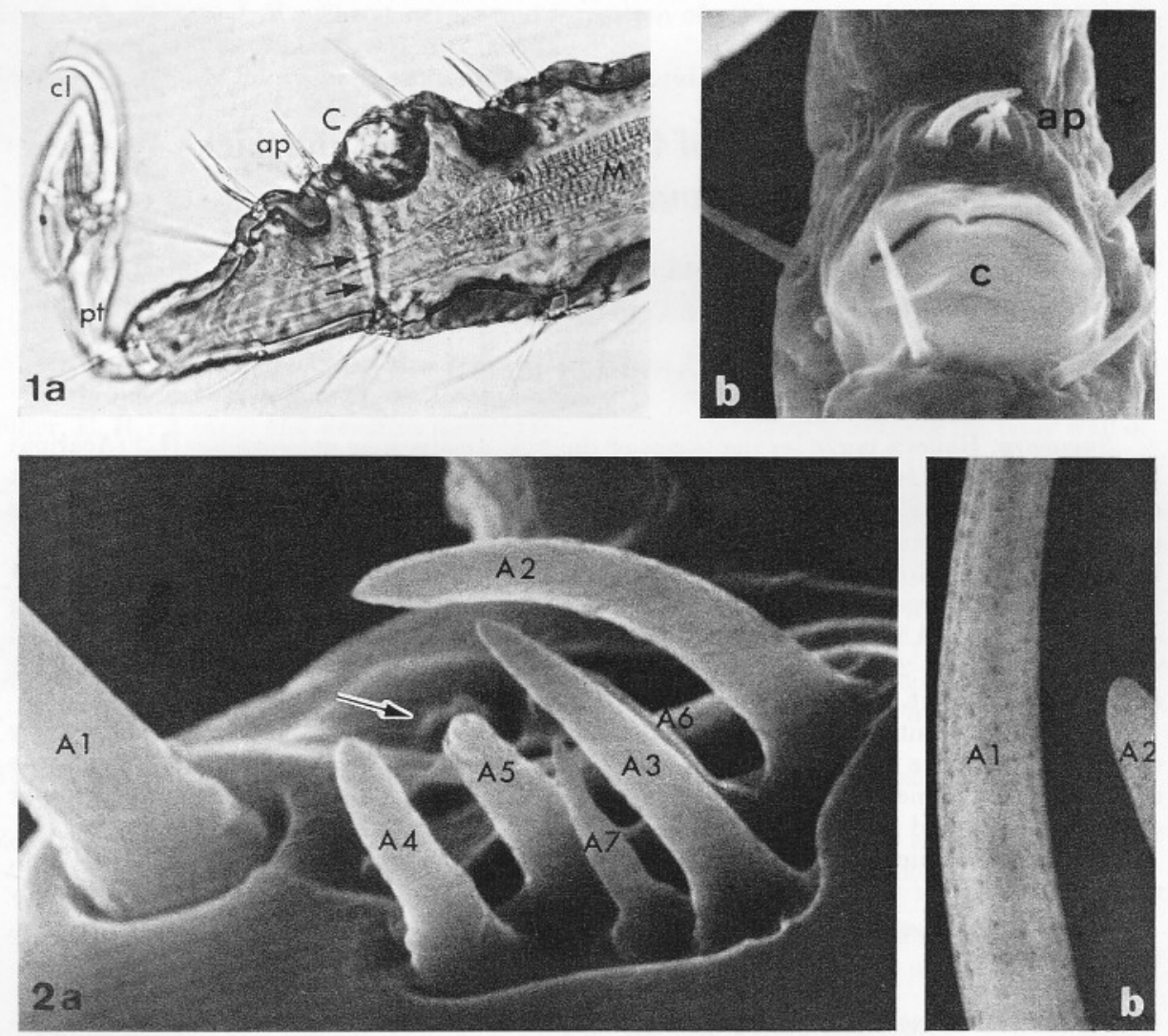

Fig. 1. a Whole mount of tarsus 1 of the tick Amblyomma americanum (nymph), lateral view. Haller's organ, located dorsally, consists of an anterior pit $(a p)$ and a capsule $(C)$. Note tarsal pseudosegmentation (arrows) between these two parts. Two claws $(c l)$ on the pretarsus $(p t)$ can be moved by two muscles $(M$; levator and depressor pretarsi). $\times 200$. b Scanning electron micrograph (SEM) of Haller's organ, dorsal view. Note bristle cluster of the anterior pit $(a p)$ and slit opening in the capsule $(c) . \times 600$

Fig. 2. a The seven sensilla $(A 1-A \gamma)$ of the anterior pit. Arrow indicates a gland opening on the leg surface. SEM $\times 4500$. b Higher magnification of the A1 and A 2 sensillum showing pores in the cuticle wall. SEM $\times 6000$

investigations (Nuttall et al., 1908) showed that this organ-which was named after its discoverer-consists of two parts (Fig. 1): A cluster of short sensory setae, termed the "accessory pit" ("anterior pit"; Lees, 1948) and immediately proximal a "capsule", which has several sensilla inside. The idea of Haller's organ being an auditory receptor was soon rejected and olfaction was proposed instead (Lahille, 1905; Hindle and Merriman, 1912). Several behavioral studies (Totze, 1933; Lees, 1948; Zolotarev and Elizarov, 1963; 1964) supported that view. Lees (1948) obtained good evidence that the anterior pit functions as a humidity receptor while the capsule subserves olfaction.

Only limited morphological information on Haller's organ is available and this is based on light microscopical investigations (Nuttall et al., 1908; Schulze, 1941; 
Zolotarev and Sinitsyna, 1965). Therefore, a fine structural study by means of electron microscopy was undertaken to elucidate the nervous supply of Haller's organ and the possible relations between receptors and environment.

\section{Materials and Methods}

Tarsi of the first legs of $A$. americanum (nymphal stage) were fixed in cold, cacodylatebuffered, $5 \%$ glutaraldehyde, post-fixed in veronal-acetate-buffered $1 \% \mathrm{OsO}_{4}$, dehydrated in graded ethanol series and embedded in hard Epon 812 over propylene oxide. Thin sections, cut with a diamond knife were picked up with Formvar-coated grids, stained with uranyl acetate and lead citrate according to the technique of Locke and Collins (1965) and examined in a Siemens Elmiskop $1 \mathrm{~A}$ at $80 \mathrm{kV}$.

For light microscopy, double-stained Epon sections (Ghidoni et al., 1968) or whole mounts, previously exposed to dyes (Slifer, 1960), were studied.

A Jeol JSM 2 scanning electron microscope (SEM) was used for studying distribution and surface structures of various sensilla. Both unfixed and glutaraldehyde-fixed ticks were examined after coating with gold.

\section{Observations}

\section{Anterior Pit}

The anterior pit contains seven sensilla which stand closely together on the dorsal surface of the tarsus, occupying an area of approximately $160 \mu^{2}$. The number, size and distribution of these sensilla was uniform in all specimens examined.

Table 1. Dimensions of cuticular and neural components of sensilla (A1-A7) in the anterior pit of Haller's organ

\begin{tabular}{llllllll}
\hline & $\mathrm{A} 1$ & $\mathrm{~A} 2$ & $\mathrm{~A} 3$ & $\mathrm{~A} 4$ & $\mathrm{~A} 5$ & $\mathrm{~A} 6$ & $\mathrm{~A} 7$ \\
\hline Length & $24 \mu$ & $14 \mu$ & $10 \mu$ & $9.5 \mu$ & $7.8 \mu$ & $4.6 \mu$ & $4.8 \mu$ \\
Base diameter & $3.5 \mu$ & $2.5 \mu$ & $1.9 \mu$ & $1.8 \mu$ & $2.0 \mu$ & $1.0 \mu$ & $0.9 \mu$ \\
\hline $\begin{array}{l}\text { Cuticle wall } \\
\text { thickness }\end{array}$ & $0.5 \mu$ & $0.4 \mu$ & $0.45 \mu$ & $0.47 \mu$ & $0.44 \mu$ & $0.34 \mu$ & $0.34 \mu$ \\
Pore diameter & 1000 to & 1000 to & 100 to & a & 100 to & a & a \\
& $1200 \AA$ & $1200 \AA$ & $150 \AA$ & & $150 \AA$ & & \\
\hline Dendrites $(n)$ & & & & & & & \\
in bristle shaft & 20 & 12 & $2-3$ & $2-3$ & $2-3$ & 3 & 3 \\
& branches & branches & & & & & \\
outer segments & $9(4+5)$ & 5 & 3 & 3 & 3 & 3 & 3 \\
ciliary regions & $9(4+5)$ & 5 & 3 & 3 & a & 3 & 3 \\
inner segments & $9(4+5)$ & 5 & 3 & $2(!)$ & 3 & 3 & a \\
\hline
\end{tabular}

\footnotetext{
a Not observed.

b Uncertain due to questionable micrograph.
}

As a matter of convenience, numbers (A1-A 7) were assigned to the sensilla of the anterior pit, according to size and position (Figs. 2, 3, 4; Table 1). The largest sensillum (A1) is always located towards the outside of the leg (laterad), while the 


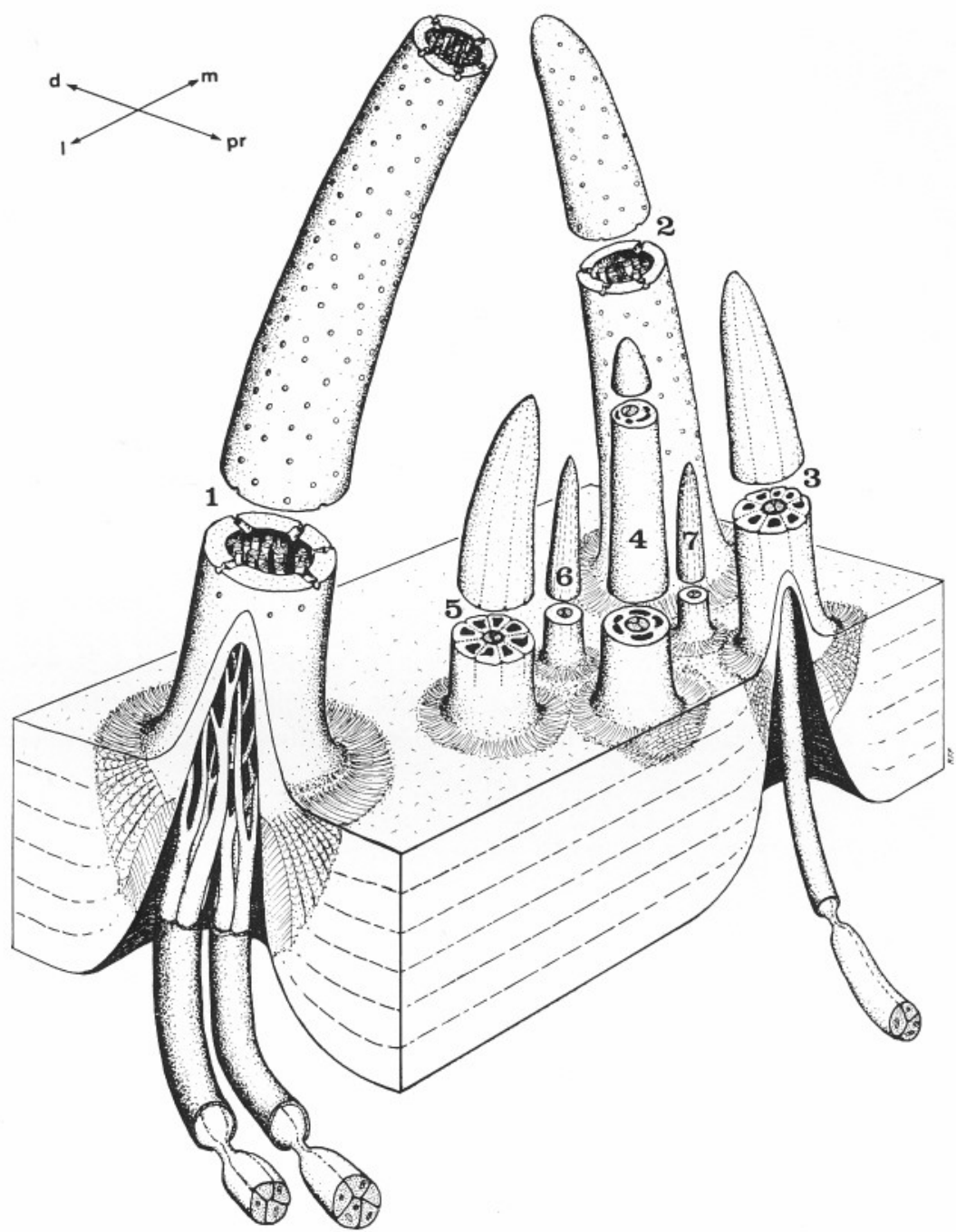

Fig. 3. Semi-diagrammatic representation of the seven anterior pit sensilla. The two largest sensilla $(1,2)$ possess plugged pores in their thick cuticle wall and dendritic branches inside the lumen. All other sensilla are provided with 2-3 unbranched dendrites. Bristles 3 and 5 have minute pores which pass through the cuticular spokes of the bristle shaft. No pores were observed in bristles 4,6 , and $\%$. Orientation: $d$ distal; $p r$ proximal; $l$ lateral; $m$ medial

other six sensilla form a cluster which is slightly separated. The fine structure of the various sensilla was observed in a sequence of cross-sections from their tips to their neuron cell bodies. At least three, possibly four, different types of sensilla were found.

1. Sensilla $A 1$ and A2. These two sensilla are located laterad and mesad, respectively, flanking the other five sensilla. They are both blunt-tipped and markedly curved, pointing toward the mid line of the tarsus. Rather evenly 


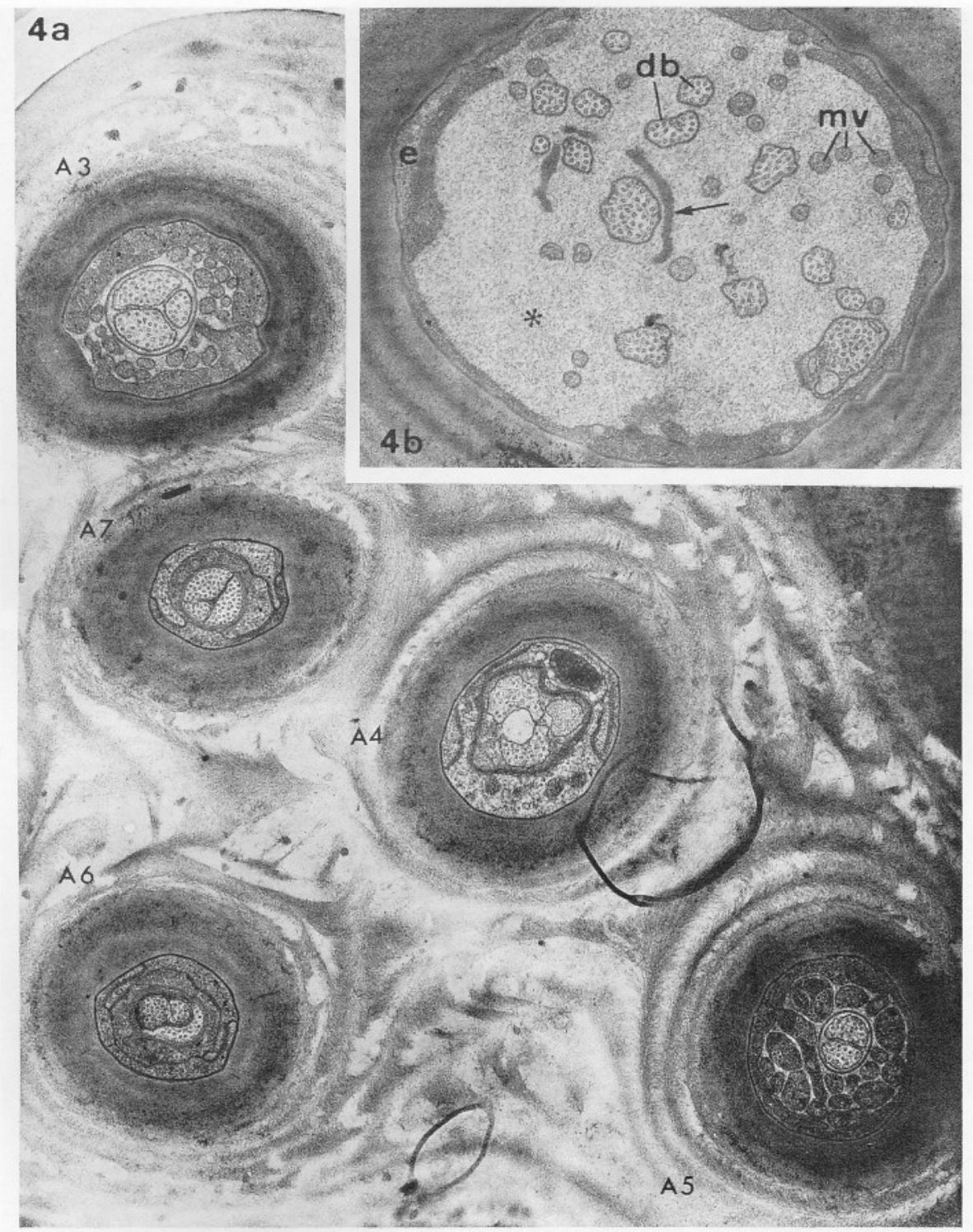

Fig. 4. a Transverse section of the anterior pit (A1 and A2 not included). Each sensillum is supplied by $2-3$ unbranched dendrites. Note concentric arrangement of socket cuticle. $\times 15500$ b Bristle A1 (shown here) and A 2 exhibit dendritic branches $(d b)$ and microvilli $(m v)$ of an enveloping cell $(e)$, bathed in a fluid $(*)$. Arrow indicates remnants of scolopale. $\times 19500$

distributed pores can be detected in their cuticular walls at high magnifications with the scanning electron microscope (Fig. 2 b). The extrapolated number of pores is 700 for A 1 and 200 for A 2 (calculated from scanning electron micrographs). The relatively large pores (1000-1200 $\AA$ in diameter) are provided with a 

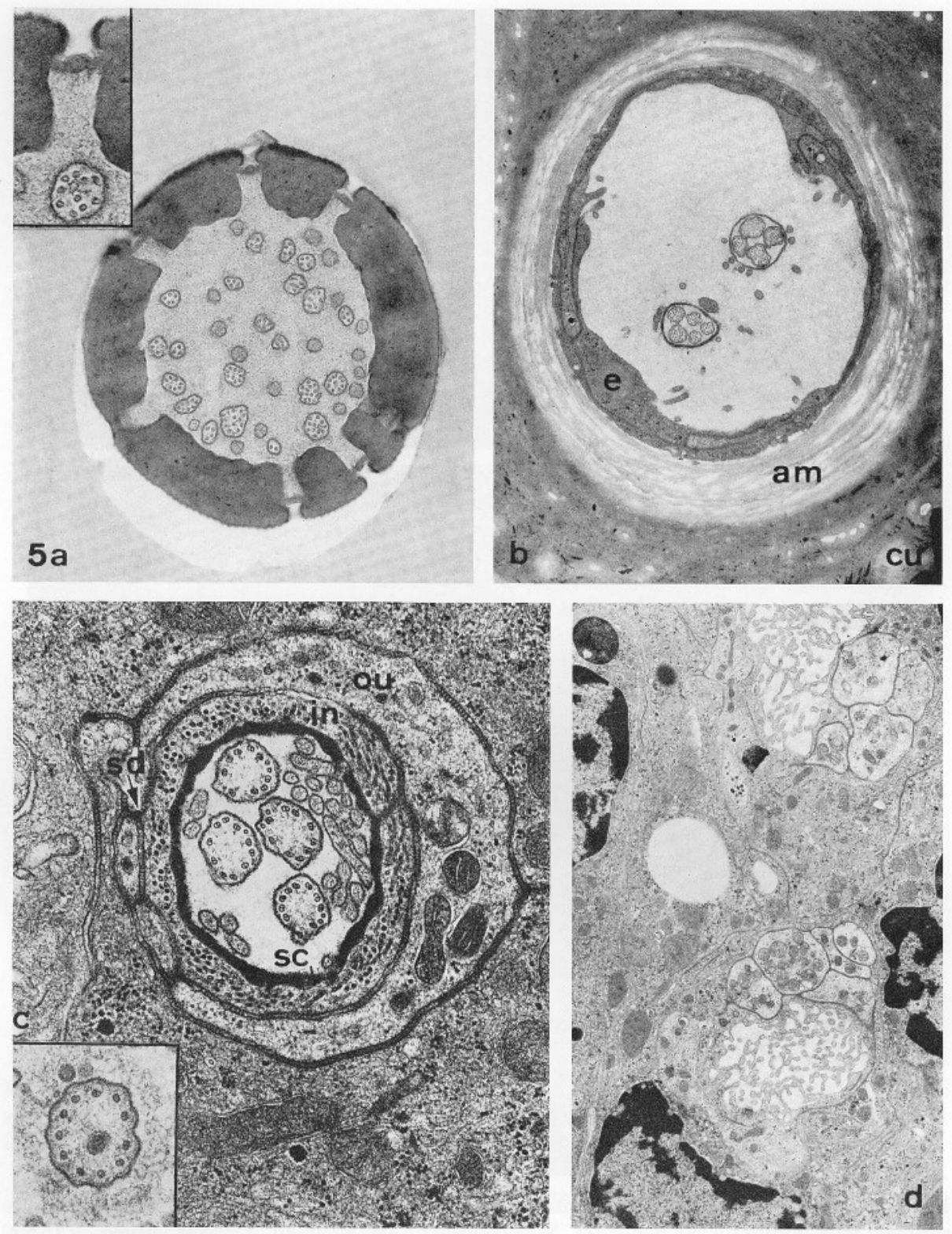

Fig. 5 a-d. Consecutive cross-sections of the A1 sensillum (from distal to proximal). a Thick cuticle wall with plugged pores (inset, $\times 36000$ ); lumen fluid-filled with microvilli and 21 dendritic branches. $\times 15500 . \mathrm{b}$ At the base level two separate bundles of 4 and 5 dendrites each can be recognized. $c u$ cuticle; am articulating membrane; $e$ enveloping cell. $\times 8000$. c Above the ciliary region the outer dendritic segments show mainly double-tubules at the periphery. The inner enveloping cell $($ in $)$ has numerous microvilli and is interconnected to the outer enveloping cell $(o u)$ by septate desmosomes $(s d)$. $s c$ scolopale. $\times 24000$. Inset: Ciliary region with typical " $11+0$ " arrangement of double-tubules. Note precipitation surrounding dendrite. $\times 26000$. d The 4 and 5 inner dendritic segments are still grouped in two separate bundles, while surrounded by hypodermis cells (compare with $5 \mathrm{~b}$ ). $\times 5300$ 


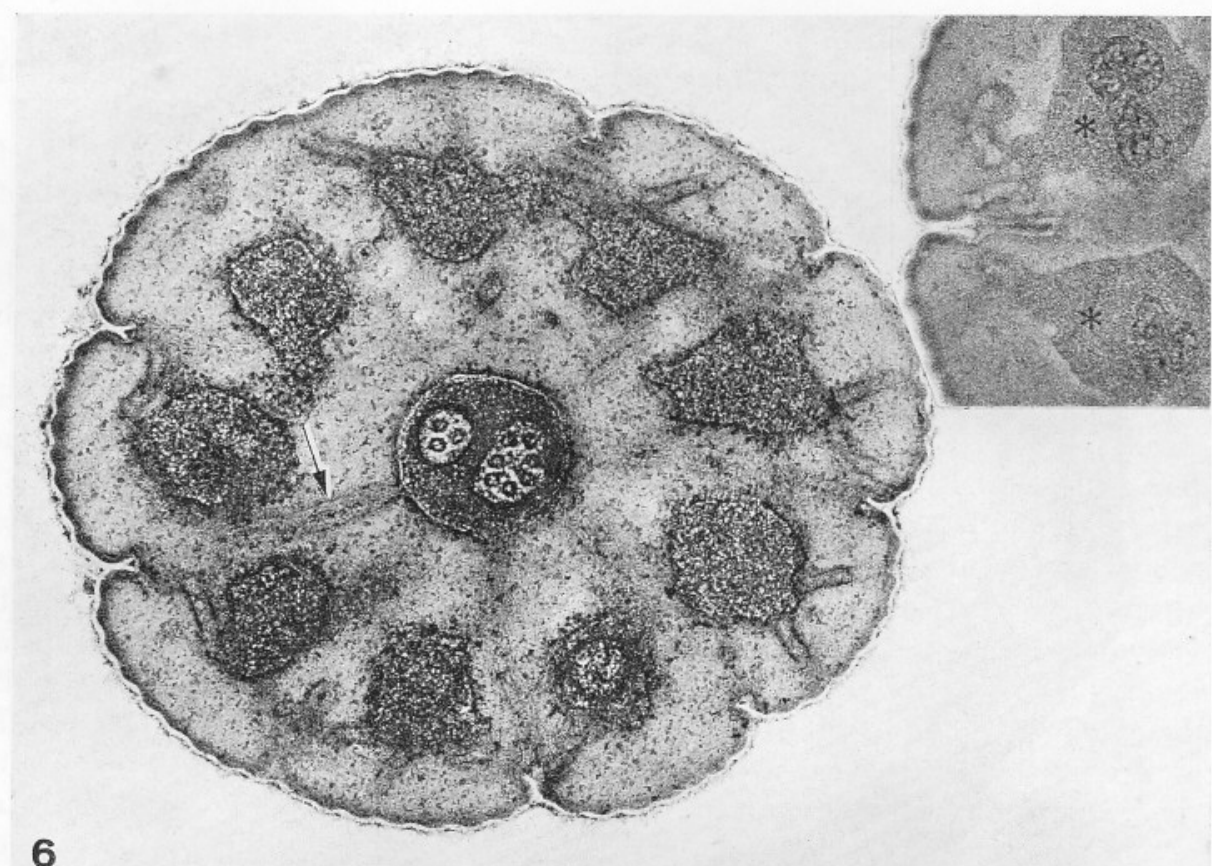

Fig. 6. Transverse section of A3 sensillum showing spoke-wheel arrangement of cuticle and pore canals (arrow) which connect two dendrites to the outside. $\times 62000$. Inset: Part of a transverse section of the A5 sensillum. Termination of a pore canal in a longitudinal groove on the bristle surface. Interspaces (*) between cuticular spokes are fluid-filled and may contain processes of an enveloping (?) cell. $\times 52000$

lens-shaped, cuticular plug in the center (Fig. 5a), suspended by fine strands. The same pore type has been previously noted in another sensillum on the first tarsus of A.americanum (Foelix and Axtell, 1971). The cuticle wall measures about $0.5 \mu$ and therefore both sensilla are considered to be thick-walled. The lumen is filled by branches of several dendrites, bathed in a fluid ("Sensillenliquor"; Ernst, 1969). A 2 is provided by five dendrites whereas A 1 has nine dendrites: One group of five and another of four, each enclosed in a cuticular sheath (scolopale) of its own (Fig. 5b). This double-innervation is unusual and has not been reported in other arthropod sensilla. The dendritic branching starts at the bristle base, where the scolopales terminate (Fig. 4 b). Further proximally we find two separate bundles of four and five dendrites, which represent the outer dendritic segments. The ciliary region is identical to that found in other tick sensilla (Foelix and Axtell, 1971) by having eleven double-tubules (" $11+0$ "; Fig. 5c) and two basal bodies with rootlets. Each dendrite bundle is encompassed by an inner and an outer enveloping cell, which are interconnected by septate desmosomes. The inner dendritic segments (Fig. 5d) show the usual array of microtubules, mitochondria and translucent vesicles; apparently these vesicles arise from pinocytosis which takes place just underneath the ciliary region (see Fig. 11). The course of the inner segments toward the neuron cell body was not followed further. 
R. F. Foelix and R. C. Axtell:

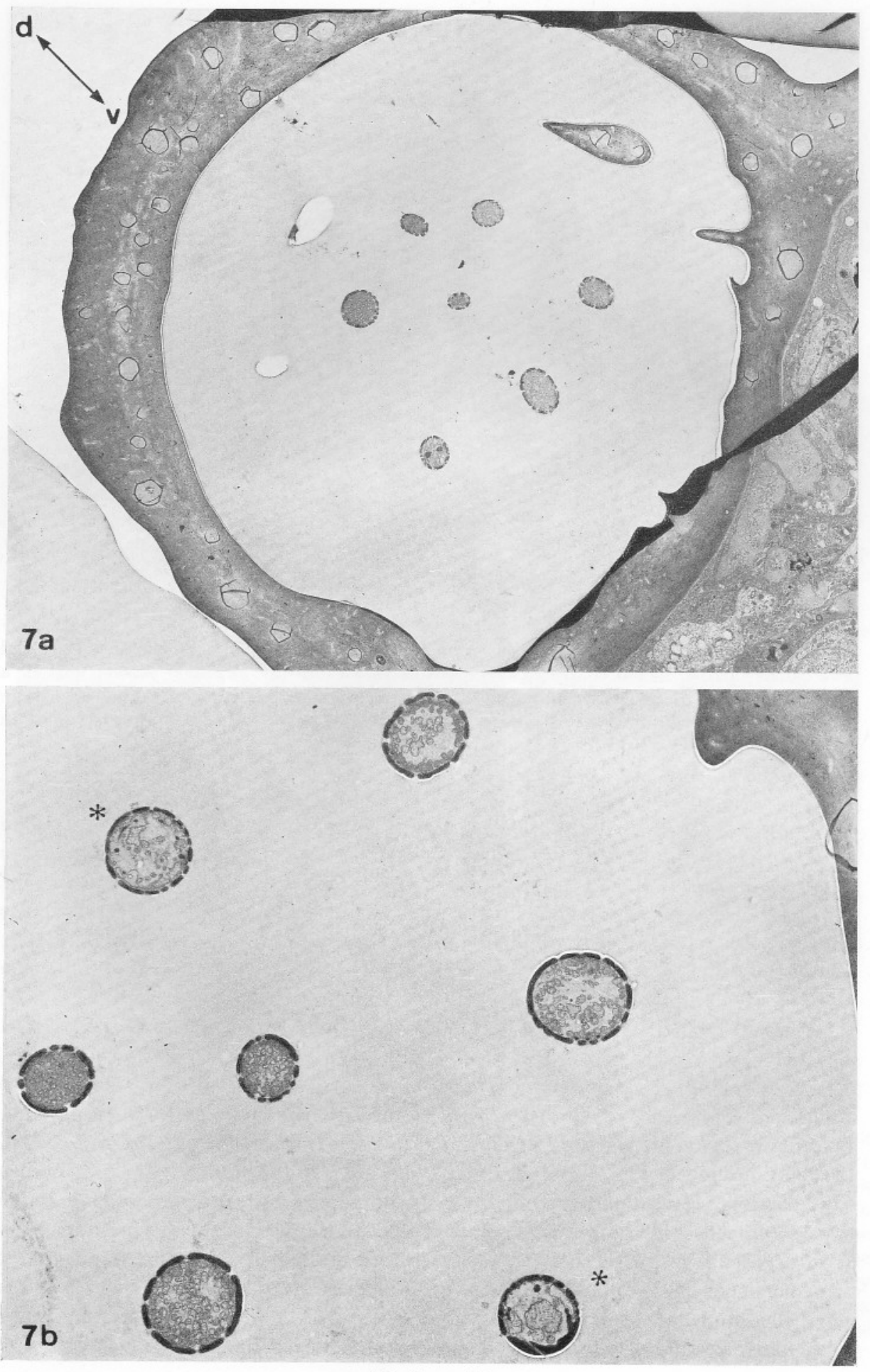

Fig. $7 \mathrm{a}$ and $\mathrm{b}$ 
The same fine structural relations as described for the A 1 bristle were found for all other sensilla of the anterior pit, unless stated otherwise.

2. Sensilla A3 and A5. These thick-walled sensilla are slightly scalloped and bear 8-10 grooves running longitudinally on the surface. Both bristles are supplied by three dendrites which enter the base, but usually only two dendrites run through the entire length of the bristle shaft. The third dendrite is already much smaller in diameter at the level of the base and fades out distally, while the other two dendrites are still enclosed by a dense scolopale. On the way towards the tip this scolopale increases in thickness and attaches to the cuticle wall at several points. Further distally, a cross-section of the bristle shaft shows a spoke-wheel arrangement of cuticle and two dendrites occupying the "hub" (Fig. 6). Fine canals (300-400 $\AA$ in diameter) pass from the center ("hub") through the spokes and end in the longitudinal grooves on the bristle surface. The two dendrites are surrounded by an electron-dense substance which also invades the spoke canals. The final pore opening is only $100-200 \AA$ wide and has a minute, pointed structure in its center (Fig. 6, inset). Interspaces between each cuticular spoke are mostly filled by cellular projections (presumably of an enveloping cell) or by some fluid. The spoke-wheel structure becomes less regular toward the tip: Some spokes break down and various interspaces fuse. However, the two dendrites in the center were always surrounded by a cuticular tube, even after most spokes had dropped out near the tip.

3. Sensilla A6 and A\%. These two short sensilla stand in the center of the anterior pit, closely surrounded by the A 2, A 3, A 4 and A 5 bristles. Unlike all the other bristles they possess a rather pointed tip. Ten to eighteen narrowspaced grooves run longitudinally along the hair shaft. Both sensilla are thick-walled with a simple circular central lumen containing three unbranched dendrites. No pore system is present in the bristle shaft but one micrograph suggests a single pore opening close to the tip.

4. Sensillum A4. This bristle resembles A 3 and A5 in shape and size; the surface is only very slightly scalloped and does not bear any longitudinal grooves (Fig. 3). A scolopale enclosing three dendrites makes contact with the thick-walled bristle shaft. However, the cuticular wall does not form a regular spoke-wheel pattern as in the A3 and A5 bristles and no pores could be detected. The connection to the outside is presumably established by a single pore opening at the tip. The neural components showed one deviation, namely three outer dendritic segments versus only two inner segments. The only plausible explanation for that discrepancy is that one inner dendritic segment gave rise to two ciliary regions and subsequently to two outer segments. Two ciliary regions arising from one dendrite were found consistently in chemosensory receptors of crustaceans (Ghiradella et al., 1968) and in trichobothria of a myriapod (Haupt, 1970) but are certainly an exception for tick sensilla.

Fig. 7. a Cross-section of the capsule of Haller's organ (arrows indicate dorso-ventral axis). Seven sensilla and two non-sensory pleomorphs are seen. $\times 1870$. b All capsule sensilla are thin-walled and provided with large, plugged pores. The lumen is filled by dendritic branches and microvilli of an enveloping cell. Note two sensilla $\left({ }^{*}\right)$ with cuticle projecting into the lumen. 

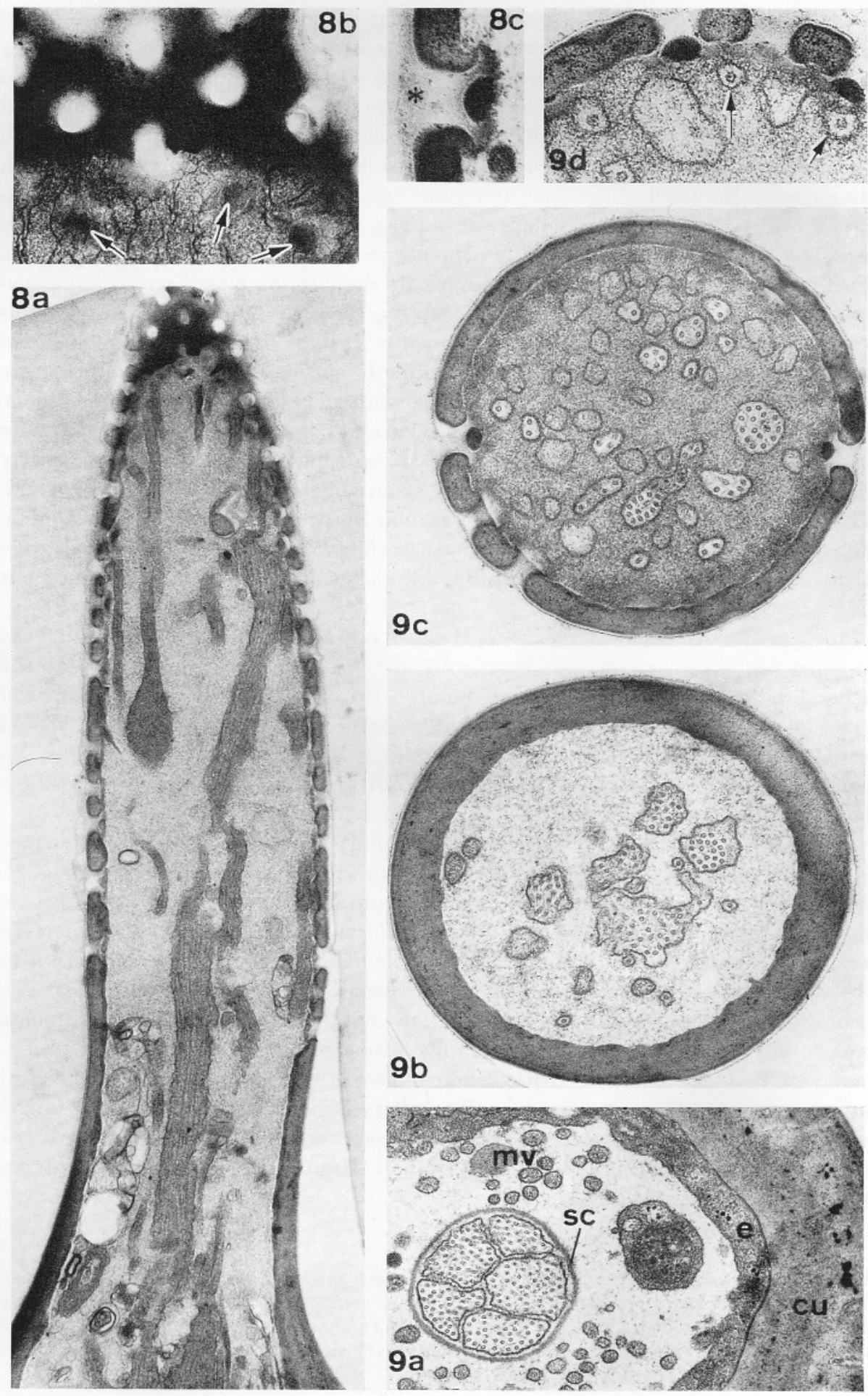

Figs. 8 and 9 


\section{Capsule}

The capsule of Haller's organ is formed by a cuticular pit $30-40 \mu$ in diameter. A narrow slit $(1-3 \mu$ wide, $40 \mu$ long $)$ on the dorsal side of the tarsus permits communication to the outside. The interior of the capsule is equipped with several non-sensory cuticular projections (pleomorphs) and seven blunt-tipped sensilla which emerge from the proximal capsule wall, pointing distally toward the capsule slit (Fig. 7). Unlike all other tarsal bristles they are non-socketed and extremely thin-walled $(0.1-0.2 \mu)$ (Fig. 8a). The distal two thirds of the hair shaft (15 $\mu$ long, $2-3 \mu$ in diameter) is evenly perforated by large, plugged pores of $1000-1300 \AA$ in diameter (Fig. 8b, c). The lens-shaped, cuticular plugs measure $1200-1400 \AA$ in diameter and are suspended from the inner pore edge by some fibrous material. Since there are $10-12$ pores $/ \mu^{2}$ one sensillum has approximately 500 pores.

Each sensillum is supplied by $3-5$ dendrites which lose their scolopales at the bristle base and start branching (Fig. 9a-c). The degree of branching is definitely greater than in the A 1 and A 2 sensillum of the anterior pit, but varies in different capsule sensilla. Most sensilla contain 25-35 dendritic branches but in two sensilla only 12 branches were present; the maximal number counted was 45 . The finest dendritic branches are $700-800 \AA$ in diameter and possess only one microtubule in the center. These delicate branches are often closely apposed to the plugged pores (Fig. 9d). A number of non-sensory cell processes, presumably extensions of an enveloping cell (trichogen cell), also invade the bristle lumen and occupy the periphery. They are more electron-dense than the dendritic branches and do not possess microtubules (Fig. 10). In some sensilla large cuticular projections were noted extending from the inner side of the bristle wall into the lumen (Fig. $7 \mathrm{~b}$ ). About $12 \mu$ proximal of the bristle base lie the ciliary regions of the dendrites (Fig. 11), which again possess the " $11+0$ " configuration. All cytological details with respect to dendrites and enveloping cells are the same as described for the A 1 bristle of the anterior pit.

It should be noted that in whole mounts, which had been exposed to methylene blue prior to mounting in resin (Euparal), only the capsule sensilla, the A 1 and A 2 bristle of the anterior pit and one distal bristle $\left(\mathrm{d}_{1}\right)$ became stained, but none of the other sensilla on the tick leg. The same sensilla - and only these-are equipped with large, plugged pores.

Fig. 8a-c. Capsule sensillum. a Longitudinal section showing thin wall with plug-pores and lumen with dendritic branches. $\times 13500$. b Tangential section of cuticular wall and underlying dendritic branches. Note regular distribution of pores and surface view of several plugs (arrows). $\times 40000$. c Sagittal section of a plugged pore. A lens-shaped cuticular body is attached to the inner hair wall by fine strands. The pore itself is filled by some unknown material ${ }^{*}$ ) which coats the surface of the sensillum. $\times 55000$

Fig. 9a-d. Consecutive cross-sections (from proximal to distal): a Five dendrites, surrounded by a scolopale $(s c)$, enter the extra-cellular space below the bristle base; $m v$ microvilli of enveloping cell $(e)$, cu cuticle. $\times 21000 . \mathrm{b}$ The scolopale terminates at the base and the five dendrites start branching (compare Fig. 10). Note five delicate branches, each with only one microtubule. $\times 22500$. c Pores appear in the distal $2 / 3$ of the bristle shaft. Lumen is occupied by dendritic branches and microvilli, bathed in a fluid ("Sensillenliquor"). $\times 26500$. d Finest dendritic branches ( $700 \AA$ in diameter) are often in close apposition to plugged pores. Most microtubules possess a center element (arrows). $\times 53000$ 

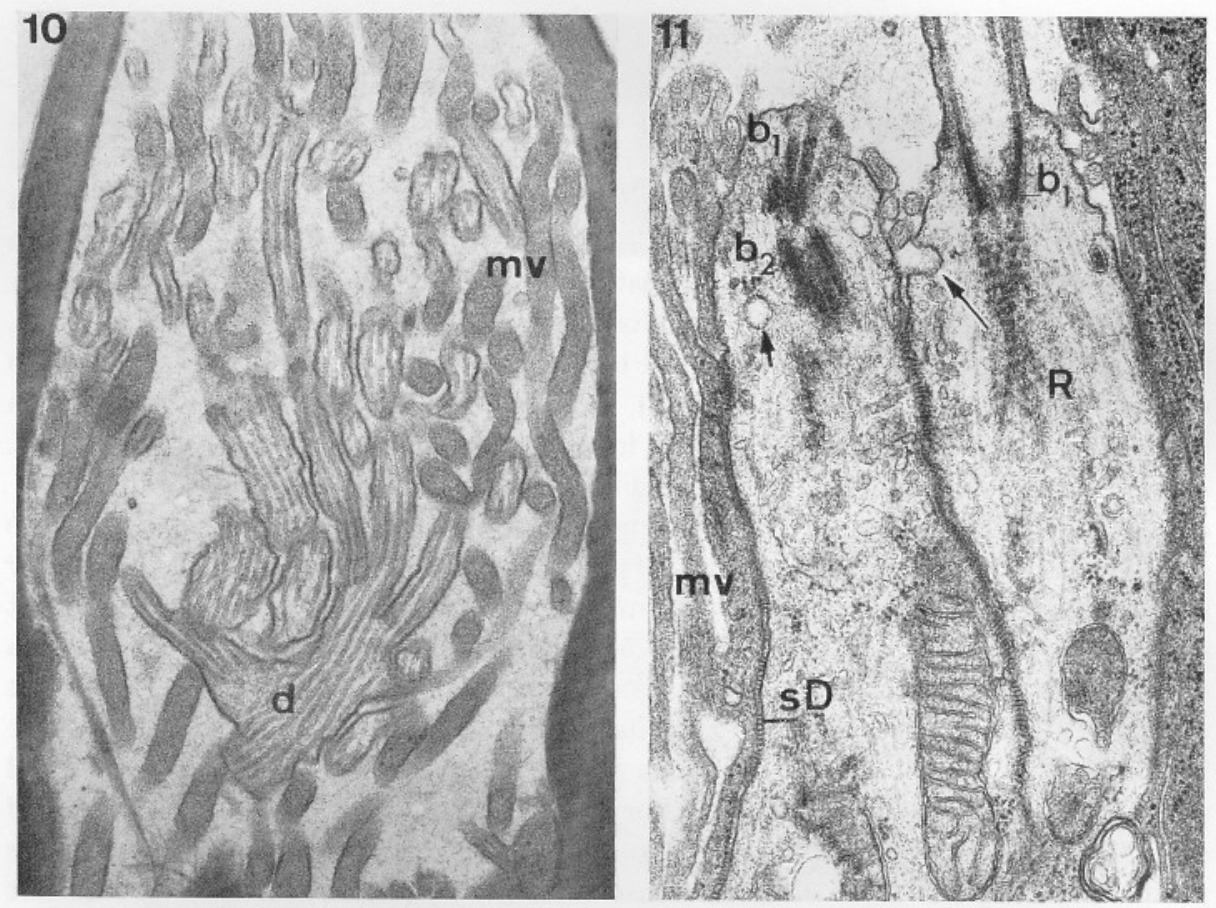

Fig. 10. Longitudinal section of a capsule sensillum; basal region. 4-5 branches emerge from one dendrite $(d)$ and pass into the bristle lumen, together with long microvilli ( $m v$ ) of an enveloping cell. $\times 23000$

Fig. 11. Ciliary region of two dendrites of a capsule sensillum in longitudinal section. Two basal bodies $\left(b_{1}, b_{2}\right)$ with striated rootlets $(R)$ (periodicity about $650 \AA$ ) lie at the transition zone between outer and inner dendritic segment. Some electron-lucent vesicles (short arrow) are probably the product of pinocytosis (long arrow) occuring in that region. Septate desmosomes $(s D)$ connect dendrites to each other and to the inner enveloping cell. $\times 22500$

The surface of the capsule sensilla is often covered by a layer of extracellular material (Fig. 8c). This substance was particularly pronounced in material simultaneously fixed with glutaraldehyde-O $\mathrm{sO}_{4}$ (Franke, et al. 1969). In whole mounts, granular or coalesced material ("Otolithen", Haller, 1881; "Sekretballen", Schulze, 1941) could be identified in many capsules but the same material (secre-

Fig. 12. Multicellular gland underlying the capsule of Haller's organ. a Each gland cell is characterized by a large nucleus $(N)$, situated at the base, an apical microvillar cell border and large lipid droplets $(l i)$ in the cytoplasm. Arrow indicates a small nerve fiber in the gland Iumen $(l u) . \times 3200$. Inset: This nerve fiber is accompanied by a glial cell process and ensheathed by a dense coat. $\times 30000$. b At higher magnification typical cell organelles and inclusions can be resolved: rough endoplasmic reticulum $(E R)$, a Golgi-complex $(G)$, mitochondria $(m)$, lipid droplets $(l i)$ and rosettes of glycogen $(G l y)$. A thin basement membrane $(B m)$ covers the outside of the gland, sometimes also enclosing a neurosecretory-type axon $(A x)$. $\times 16000$. Inset: Small, light vesicles empty into the lumen $(l u)$ at the base of microvilli $(m v) . \times 23000$ 

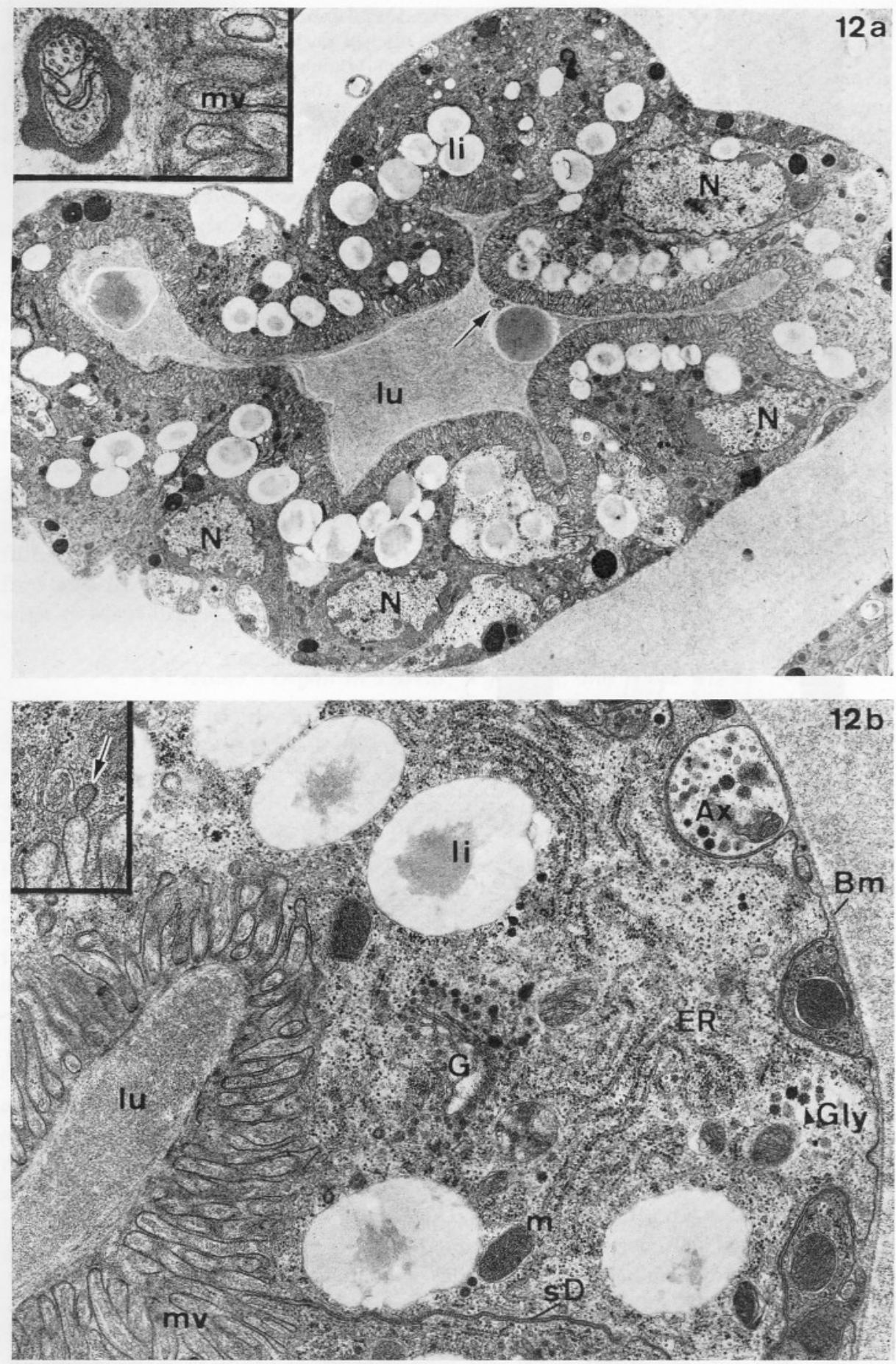

Fig. 12a and b 


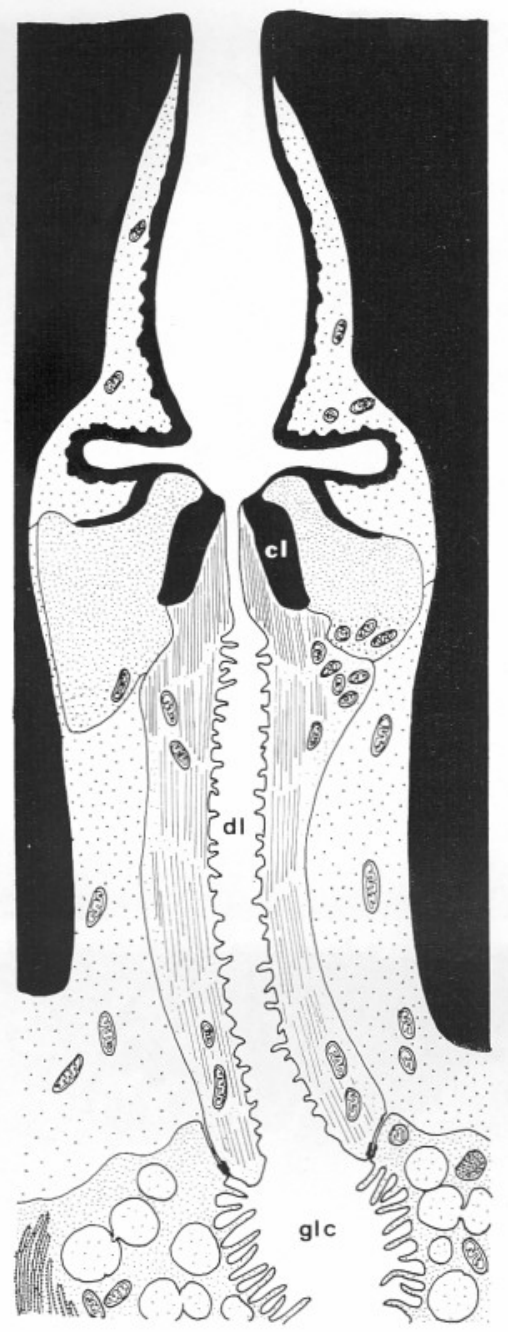

Fig. 13. Diagrammatic longitudinal section of the duct of an integumental gland. Secretory product originates from two gland cells $(g l c)$ and passes through the duct lumen $(d l)$ and two cuticular lips $(c l)$ to the surface

tion) was absent in all electron micrographs. This may be due to the cleaning action which certainly takes place during processing the specimens for histological purposes (Lees, 1948).

\section{Gland}

A large, multicellular gland occupies most of the hemolymph space underneath the capsule and glandular openings were found in the capsule wall (Figs. 12, 13). Each gland cell is laterally connected to the adjacent one by septate desmosomes, while the apical cell border shows numerous microvilli with a fibrous surface coating. The cytoplasm has distinct profiles of rough endoplasmic reticulum, active Golgi-fields, mitochondria, free ribosomes and inclusions of lipids and glycogen. Light vesicles of $1000-2000 \AA$ in diameter, probably originating from a Golgi element, open into the apical membrane invagination, at the base of the microvilli (Fig. $12 \mathrm{~b}$, inset). The secretory product filling the gland lumen is fine granular and homogeneous. 
Some neurosecretory-type axons occur at the cell base, carrying dense granules of 1000-1300 $\AA$ diameter. A very small nerve fiber, accompanied by a glial (?) cell process and enclosed by a dense coat, was found inside the gland lumen (Fig. 12a, inset). Although its significance is not known, it is likely to belong to some kind of sensory receptor. The same type multicellular gland, also with a small nerve fiber in the lumen, was found in the palp (Foelix and Chu, in prep.).

We did not obtain micrographs showing the actual opening of the multicellular gland into the capsule. The glandular ducts usually found in the capsule wall belong most likely to bicellular glands (Yalvaç, 1939; Lees, 1947), which occur throughout the tick's cuticule (Fig. 13). Those glandular ducts are characterized by two complex cuticular lips, which continue into a thin cuticular lining until reaching the surface of the leg or the capsule wall, respectively. There, accumulations of secretory globules can be observed in whole mounts or under the SEM. An elongated, centrally pierced cell connects the cuticular lips to the gland cell proper, which is filled by large, sometimes confluent, vesicles.

We believe that these integumentary glands correspond to those structures described as "sensilla hastiformia" ("Krobylophoren") by Schulze (1942). Schulze claimed that these organs consist of a neural and a glandular part and should function as "vibro-chemoreceptors". Lees (1947, 1948), however, was unable to find any innervation of these integumental glands, a fact which we can confirm with electron micrographs.

\section{Haller's Organ in Larval, Nymphal, and Adult Forms}

Haller's organ is present in all three developmental stages and according to Schulze (1941) there is no essential difference between larval and adult forms with respect to the structure of this organ. Our observations with the SEM are in good agreement with those of Schulze, except for the larva. The anterior pit of the larva apparently contains 5 sensilla only; A 1 stands laterad and is provided with large pores, while A 2 is not developed; the other bristle missing is A 3 or A4. Besides a continuous increase in size between the different developmental stages $(10 \mu-$ $20 \mu-35 \mu$ in length) the A 1 sensillum also shows an increase of pore density from the nymph to the adult form. While larvae and nymphs possess $5-7$ pores $/ \mu^{2}$, adult have about 12 pores/ $\mu$. The combination of both factors (increased surface area, increased density) yields a much higher pore number in the adult.

The capsule slit is U-shaped in larvae and the capsule roof is often perforated, or at least indented. Nymphs and adults have a double-S-shaped capsule opening and lack perforations in the roof. The enclosed capsule sensilla are normally not accessible for studying with the SEM but recently Bruce (1971) was successful in opening the capsule partially. In his SEM pictures he counted 8 bristles for the adult form of Amblyomma americanum. There is, however, a strong possibility that only seven are sensory, while the eighth may be a solid cuticle spine-as we showed in the nymph by means of transmission electron microscopy (Fig. $7 \mathrm{a}$ ).

\section{Diseussion}

An unexpected finding was the diversity of sensilla within the anterior pit. Two bristles (A1, A 2) have the same structure (large, plugged pores, and dendritic branches) as described for another tarsal tick sensillum (Foelix and Axtell, 1971) 
and most likely represent a thick-walled chemoreceptor. Bristles A3 and A5 possess a specific spoke-wheel arrangement of the cuticle shaft, which has not been found in any other tarsal tick sensillum. Very similar micrographs have been obtained from Sensilla coeloconica on a grasshopper's antenna (Steinbrecht, 1969). These sensilla have also been studied electrophysiologically (Waldow, 1970) and, although morphologically indistinguishable, two different types were observed physiologically : they are either purely olfactory or they respond to humidity and temperature changes. It is tempting to assume the same functions for the A3 and A5 sensilla, especially since Lees (1948) postulated that the anterior pit is responsible for humidity perception. However, an electrophysiological proof is necessary in order to designate a certain function to a specific sensillum.

For the A4, A 6, and A 7 sensillum, no communication to the outside could be demonstrated, but this failure can be explained if we assume a single opening close to the tip, which is easy to miss during sectioning (see note added to proof).

Common to all sensilla of the anterior pit is a thick cuticular wall and multiple innervation. In contrast to many other tarsal tick sensilla, there are no mechanoreceptive dendrites at the bristle base, although all of them are socketed. The morphological diversity of sensilla (3-4 types) suggests that the anterior pit subserves several functions : possibly chemo-, humidity, and temperature reception.

Several physiological and behavioral studies (Hindle and Merriman, 1912; Totze, 1933; Lees, 1948; Zolotarev and Elizarov, 1963) demonstrate the olfactory function of the capsule in Haller's organ. The capsule contains seven thin-walled sensilla, which correspond morphologically in most details to olfactory receptors (Sensilla basiconica) in insects (Slifer, 1970; Ernst, 1969; Steinbrecht, 1969). The bristle lumen is filled by numerous dendritic branches and the thin cuticle wall is perforated by many pores. The main differences compared to insect olfactory sensilla (Schneider and Steinbrecht, 1968) are relatively large, plugged pores and microvilli of an enveloping cell which invade the bristle lumen. Plugged pores occur also in thick-walled tick sensilla (A1, A 2 of the anterior pit; $\mathrm{d}_{1}$ of the "distal" bristles) and their structure poses several questions: a) Is the plug movably suspended and thus possibly regulating water exchange with the environment? The distance between plug and pore appears always the same, even in micrographs of different individuals. However, it would be interesting to observe this gap in ticks, which had been exposed to low humidities for an extended period of time. If there is a regulating function associated with the plugs, the cleft should be reduced or completely closed. b) How is contact to the atmosphere achieved since no distinct tubes (pore tubules) are present inside the pore opening, as they occur in insect olfactory sensilla? We must assume that the material suspending the plug is permeable to odor molecules, since it is certainly this material which also permits the entry of dyes. Penetration experiments with silver-protein solutions (Ernst, 1969) are in progress to test the permeability relations in these plugged pores on the ultrastructural level.

Whether the odor molecules have to diffuse into the sensillar fluid ("Sensillenliquor", Ernst, 1969) first before stimulating the dendritic membrane or whether they affect directly those dendritic branches apposing the plugs (Fig. 9d) cannot be decided at present. In insect olfactory sensilla there is now increasing evidence 
that the pore tubules are in direct contact with dendritic membranes (Myers, 1968; Steinbrecht, 1970 and personal communication; Borg and Norris, 1971).

In this connection the surface coating of the capsule sensilla should be pointed out. This coating was only prominent after a simultaneous glutaraldehyde $-\mathrm{OsO}_{4}$ fixation, but we believe that it corresponds closer to the in vivo state than following the normal post-osmication procedure. Analogous to the mucus layer covering vertebrate olfactory epithelia this coating might provide a substrate for the diffusion of odor molecules. We do not know the origin of this material, but there is a possibility that the multicellular gland, which underlies the capsule, might be involved. A slight surface coating was also found in certain tarsal sensilla of a mite (Coons, 1970).

One might expect that the enclosed capsule sensilla are so well shielded from the environment that they could hardly function as olfactory receptors. Yet, ticks wave their first pair of legs in a similar fashion as insects wave their antennae and do not use them for walking (except for the larvae). An alternating up and down movement of the first pair of legs (Totze, 1933) certainly facilitates perception of olfactory stimuli. The capsule is considered to serve mainly as a protection device since the thin-walled and non-socketed capsule sensilla could easily be damaged mechanically.

\section{References}

Borg, T. K., Norris, D. M.: Ultrastructure of sensory receptors on the antennae of Scolytus multistriatus (Marsh.). Z. Zellforsch. 113, 13-28 (1971).

Bruce, W. A.: Posterior capsule of Haller's organ in the lone star tick Amblyomma americanum (Acari: Ixodidae). The Florida Entomol. 54, 65-72 (1971).

Coons, L. B. : Fine structure of selected organ systems of the mite Macrocheles muscaedomesticae (Acarina; Mesostigmata; Macrochelidae). Doct. thesis, N. C. State Univ., Raleigh, N. C. (1970).

Ernst, K. D. : Die Feinstruktur von Riechsensillen auf der Antenne des Aaskäfers Necrophorus (Coleoptera). Z. Zellforsch. 94, 72-102 (1969).

Foelix, R. F., Axtell, R. C.: Fine structure of tarsal sensilla in the tick Amblyomma americanum (L.). Z. Zellforsch. 114, 22-37 (1971).

Franke, W.W., Krien, S., Malcolm Brown, R. : Simultaneous glutaraldehyde-osmium tetroxide fixation with postosmication. An improved fixation procedure for electron microscopy of plant and animal cells. Histochemie 19, 162-164 (1969).

Ghidoni, J. J., Campbell, M. M., Adams, J. G., Thomas, H., Ramos, E. E.: A new multicolored staining procedure for one micron section of epoxy embedments. Proc. Electr. Micr. Soc. 26th Meeting, New Orleans, p. 240-241 (1968).

Ghiradella, H. T., Case, J. F., Cronshaw, J.: Structure of aesthetases in selected marine and terrestrial decapods: Chemoreceptor morphology and environment. Amer. Zoologist 8, $603-621$ (1968).

Haller, G.: Vorläufige Bemerkungen über das Gehörorgan der Ixodiden. Zool. Anz. 4, 165-167 (1881).

Haupt, J.: Beitrag zur Kenntnis der Sinnesorgane von Symphylen (Myriapoda). I. Elektronenmikroskopische Untersuchung des Trichobothriums von Scutigerella immaculata Newport. Z. Zellforsch. 110, $588-599$ (1970).

Hindle, E., Merriman, G.: The sensory perceptions of Argas persicus (Oken). Parasitology $\mathbf{5}$, 203-216 (1912).

Lahille, F.: Contributions a l'étude des Ixodides de la République Argentine. Anales del Minist. Agric. Sección de Zootecnica, (Buenos Aires) 2, 107-109 (1905).

Lees, A. D.: Transpiration and the structure of the epicuticle in ticks. J. exp. Biol. 23, 379-410 (1947).

— The sensory physiology of the sheep tick, Ixodes ricinus L. J. exp. Biol. 25, 145-207 (1948). 
Locke, M., Collins, J. V.: The structure and formation of protein granules in the fat body of an insect. J. Cell Biol. 26, 857-884 (1965).

Myers, J.: The structure of the antennae of the Florida queen butterfly, Danaus gilippus berenice (Cramer). J. Morph. 125, 315-328 (1968).

Nuttall, G. H. F., Cooper, W. F., Robinson, L. E.: On the structure of Haller's organ in the Ixodoidea. Parasitology 1, 238-243 (1908).

Schneider, D., Steinbrecht, R. A.: Checklist of insect olfactory sensilla. Symp. zool. Soc. Lond. 23, 279-297 (1968).

Schulze, P.: Das Geruchsorgan der Zecken. Untersuchungen über die Abwandlungen eines Sinnesorgans und seine stammesgeschichtliche Bedeutung. Z. Morph. Ökol. Tiere 37, 491-564 (1941).

- Úber die Hautsinnesorgane der Zecken, besonders über eine bisher unbekannte Art von Arthropodensinnesorganen, die Krobylophoren. Z. Morph. Ökol. Tiere 38, 379-419 (1942).

Slifer, E. H.: A rapid and sensitive method for identifying permeable areas in the body wall of insects. Entom. News 71, 179-182 (1960).

- The structure of arthropod chemoreceptors. Ann. Rev. Entomol. 15, 121-142 (1970).

Steinbrecht, R. A.: Comparative morphology of olfactory receptors. In: Olfaction and taste, ed. by C. Pfaffmann, p. 3-21. New York: Rockefeller Univ. Press 1969.

- Stimulus transfering tubules in insect olfactory receptors. Septième Congr. Int. Micr. Electr., Grenoble, p. 947-948 (1970).

Totze, R.: Beiträge zur Sinnesphysiologie der Zecken. Z. vergl. Physiol. 19, 110-161 (1933).

Waldow, U.: Elektrophysiologische Untersuchungen an Feuchte-, Trocken- und Kälterezeptoren auf der Antenne der Wanderheuschrecke Locusta. Z. vergl. Physiol. 69, 249-283 (1970).

Yalvaç, S.: Histologische Untersuchungen über die Entwicklung des Zeckenadultus in der Nymphe. Z. Morph. Ökol. Tiere 35, 535-585 (1939).

Zolotarev, E. Kh., Elizarov, Yu. A.: Studies of chemoreception in insects and ticks. Location of the chemoreceptors in the tick Ixodes persulcatus P. Sch. Vestn. Mosk. Univ. 18, 7-9 (1963).

- - Investigation of the chemoreception in insects and ticks: The pecularities of the functioning of chemoreceptors in Hyalomma asiaticum P. Sch. et E. Sch. under the action of repellents. Zool. J. Mosk. 43, 549-559 (1964).

- Sinitsyna, Ye. Ye.: Chemoreceptive organs on the fore legs of ixodid ticks. Vestn. Mosk. Univ. 20, 17-25 (1965).

Note added to proof: Recent investigations, and mainly comparative studies on the soft tick Argas (Persicargas) arboreus, show that the A4, A6 and A 7 sensilla of the anterior pit possess fine convoluted canals in their cuticle walls rather than a single opening at the tip.

Dr. R. F. Foelix

Department of Entomology

North Carolina State University

Box 5215,

Raleigh, N. C. 27607 , U.S.A 